\title{
Proceeding
}

Supplementary Issue: Autumn Conferences of Sports Science. Costa Blanca Sports Science Events, 18-19 December 2020. Alicante, Spain.

\section{Identification of effective indicators in the economic valuation model for intangible assets of Iranian FUTSAL Premier League clubs with future research approach}

\author{
HOMEIRA SHOJAEI 14 , MIR HASSAN SEYED AMERI ${ }^{1}$, MAHDI TALEBPOUR ${ }^{2}$ \\ ${ }^{1}$ Faculty of Sports Sciences, Urmia University, Urmia, Islamic Republic of Iran \\ ${ }^{2}$ Faculty of Sports Sciences, Ferdowsi University of Mashhad, Mashhad, Islamic Republic of Iran
}

\begin{abstract}
Today, the value of organizations depends on their intangible assets. The purpose of this study is to identification of effective indicators in the economic valuation model for intangible assets of Iranian FUTSAL Premier League clubs with future research approach. Research from the perspective of applied purpose and in terms of how to collect data of descriptive-survey type and in terms of the nature of data, is mixed (qualitative-quantitative) with the future research approach. The statistical population of the study included academic faculties of sport management and economics, coaches and official instructors of the Federation, as well as managers of FUTSAL clubs. Using a snowball sampling method and semi-structured interviews with 29 statistical samples, intangible assets of the FUTSAL Premier League club were identified. After reaching the theoretical saturation and coding, finally the important effective indicators were identified and extracted. After developing a questionnaire and content validation by the researcher distributed a Delphi questionnaire to instructors, coaches, and managers of FUTSAL Premier League clubs and expert faculty in FUTSAL. From the results of three Delphi rounds, 44 key indicators with 5 effective factors were extracted. The results showed that the factors of structural wealth, commercial wealth and public relations, spiritual and value wealth, human and situational wealth and communication wealth are influential in the economic valuation of intangible assets of FUTSAL clubs. Then, using Mic Mac software, diagrams, maps and analysis of identified factors were drawn, and finally 25 key indicators affecting the economic valuation of intangible assets of FUTSAL Premier League clubs were identified. Identifying these factors can be effective and fruitive in attracting more financial sponsors and the desire to invest in FUTSAL clubs.
\end{abstract}

Keywords: Economic valuation; Intangible assets; Delphi technique; FUTSAL; Mic Mac software.

\section{Cite this article as:}

Shojaei, H., Ameri, M.H.S., \& Talebpour, M. (2021). Identification of effective indicators in the economic valuation model for intangible assets of Iranian FUTSAL Premier League clubs with future research approach. Journal of Human Sport and Exercise, 16(2proc), S444-S459. doi:https://doi.org/10.14198/jhse.2021.16.Proc2.30

Corresponding author. Faculty of Sports Sciences, Urmia University, Urmia, Iran.

E-mail: hvhedi@yahoo.com

Abstract submitted to: Autumn Conferences of Sports Science. Costa Blanca Sports Science Events, 18-19 December 2020. Alicante, Spain.

JOURNAL OF HUMAN SPORT \& EXERCISE ISSN 1988-5202

(c) Faculty of Education. University of Alicante

doi:10.14198/jhse.2021.16.Proc2.30 


\section{INTRODUCTION}

Today, the value creation of organizations depends on its intangible assets (Manel et al., 2019). Intangible assets include royalties, copyrights, and business letters, are protected by law, are recognized as intellectual property, and are reflected in the organization's balance sheet (Manikas et al., 2019; Moghadam et al., 2020). These assets represent a set of capabilities and capabilities of an organization (Biachi, 2017) that have been identified as blood, life-giving knowledge industries, and competition tools for organizations and innovative systems (Rahmani and Ismaili Kia, 2014). They increase the level of productivity and gain a sustainable competitive advantage for the organization (Neabig \& Wunsch- Vincent, 2018). Intangible assets form the basis of the student creation process. These assets do not have a physical location, but they are the main source of profit for organizations (Adli and Mohammadi, 2013) and the only real source of competition that is sustainable over time (Bauman \& Shaw, 2018).

The position of the sports industry has improved among other industries, so that in most developed countries the share of the sports industry in GDP is more than $2 \%$. These assets and the large financial turnover that exists in sports are considered as valuable assets, and it is inevitable to pay attention to their valuation (Rostamzadeh, 2014). For example, the Spanish football industry was valued at 64.4 billion Euros in 2002, accounting for about $9 \%$ of the country's GDP, with 47,000 jobs already created by the country's football industry (Elahi, 2005). At the 2006 FIFA World Cup in Germany, 7,600 jobs were created and about 48 billion Euros was added to Germany's GDP. As a result, the role of the sports industry in the GDP of each country is of great importance (Fathollahzadeh, 2009).

Sports clubs are one of the main components of the sports industry. FUTSAL is one of those sports clubs that has been touted as the core of the sports industry, like an economic enterprise. Taking advantage of equipment and facilities, professional and skilled people, effective management, sports such as football and FUTSAL as industries that produce wealth, have created the ground for changes in the world of sports (Janin, 2017). FUTSAL is considered as a pervasive, attractive and social sport and an important and influential category at the national and international levels. FUTSAL clubs, as the core of the FUTSAL industry, also play a key role in the development of this sport and industry. In the Iranian FUTSAL Premier League, as in other countries, the preparation of clubs for each season of the competition always requires large amounts of material and non-material resources, and at the end of each season of the league, in addition to the results obtained and ranked to the results showed that clubs performed differently in terms of cost, available facilities, profit and loss, spectator attraction, positive social impact and other variables (Perno et al., 2013).

In sports clubs such as football and FUTSAL, it is clear that the financial situation varies from year to year and after the transfer of players. One of the factors that depends on the performance of the club is the income of that club, so that these changes in this industry are more than any other industry. So, it does not end with buying new players, and it is still unclear how the team will perform with these players. As a result, it can be said that in the case of popular sports clubs, i.e., football and FUTSAL, there is never any information that, like other organizations, indicates normal activities (Maleki, 2010). On the other hand, intangible assets and non-quantitative information have a great impact on club decisions in popular sports (football and FUTSAL) (Travassos et al., 2018). Given the growing expansion of the sports industry, and in particular the professional FUTSAL clubs, as well as the huge investments made in sports around the world, it is obvious that continuous monitoring of the various functions of these enterprises, especially in The financial dimension is necessary not only to prepare themselves for rapid environmental change, but also to make the most of the resources, facilities and capacity of the clubs, and the clubs to be efficient, effective and ultimately productive. (Asmild et al., 2009). On the other hand, estimating the monetary value of assets and services in the sports industry 
and specifically in FUTSAL can be constructive, as this is a huge part of economic activity based on converting existing wealth into revenue and headquarters. Are current. Attention to the marketing sector as well as economic approaches as a suitable solution for the economic capability of high-cost sports clubs and the use of economic tools according to the concepts of economics to solve problems and difficulties (Da Silva et al., 2018).

Past studies and research show that not only is there no specific method for valuing assets in the Iranian sports industry, but also the owners of capital have been unaware of its value and have ignored it (Hosseini, 2014). Therefore, the valuation of each asset and the determination and identification of intangible assets based on Rials and its characteristics in the field of FUTSAL and its premier league can be used to inform investors, managers of sports clubs, Officials of relevant clubs, stakeholders and stakeholders should be effective, and it is important to provide an economic and conceptual model to advance their economic goals and gain their competitive advantage (Plambeck and Taylor, 2013). Since few studies have been conducted on the valuation of sports clubs in Iran, the importance of further studies to identify non-market values, especially from various dimensions, affects the social components and also affects the fans of sports clubs. It doubles. The emergence of a club's value (economic) position among competitors and customer attraction (financial support) depends on the economic attitude of clubs as a sports brand. However, this indirectly affects the club's financial capacity. On a large scale, the bargaining of the club's most powerful executives to attract government funding could depend on such assessments. In addition, the correct economic creation or valuation of the assets of sports clubs, especially intangible assets of clubs, such as the failure or poor success of sports clubs, along with issues related to players and coaches and the lack of It has features. This issue, despite its great importance, is still neglected by the administration (Houlihan, 2015).

Christos (2014) stated in his research that there is a significant relationship between European performance and their stock returns. The results of the loss or draw in the European League have a significant relationship with the stagnation of their stock returns. Fredman and Yanovsky (2013) stated in their studies that in the first half of 2013, Latin American countries launched about 5,000 football players worth $\$ 1.1$ billion, with Argentina and Brazil alone receiving 3,000 players worth $\$ 400$ million. They issued dollars. In a study titled "The Value of the Experience of the 2018 Winter Olympics in Munich" by Preuss \& Werkmann (2011), they found that the German people were willing to pay 9 million dollars. Abdi et al. (2016) in a study examined the role of factors affecting the evaluation of players in the Iranian Football Premier League, the results of which showed; Factors such as the age of the players, the number of national games, the number of goals scored, the level of the player's previous team and the number of appearances in the regular season have affected the prices of the club's players. Izadyar et al. (2016) stated in a study entitled "Pricing of players in the Iranian Football Premier League"; Valuation factors for a player include tactics, technique, fitness, social acceptance, and club brand.

By studying the research, it can be stated that all aspects of economic valuation in sports, especially sports clubs, have not been considered, and most of these research have not paid attention to the valuations of visible assets (market). Such as stadiums, clubs, players, television broadcasting rights, and the amount of financial support in sports. Like Time Research et al. (2012), Masla et al. (2009), Biscay et al. (2013), Christos (2014). Also, most of the research in the field of sports has been either in the championship sports section and also in football clubs, or they have examined leisure and health time. These include Pamela's (2011) and Prius and Walkman's (2011) research. In addition, most of the foreign studies conducted on the valuation of players financially, stadiums, clubs, and sports venues on the outskirts of sports stadiums sought to evaluate the value of an event. And determine the share of a television broadcast, the financial sponsors of the players and the clubs, and consequently determine their future contracts in all these areas. In Iran, effective economic 
factors in clubs, barriers to privatization, productivity, and financial support were among the items mentioned in the research. Like Izdyar et al. (2016), who evaluated the value of players and Mohammadzadeh and Azizi (2015) on the effects of stadiums and sports teams in cities on people's income in Iran, he pointed out that their number was not very high and showed Not only is there no scale, criterion, or benchmark for valuing intangible assets, but the amount of apparent assets of a club that has market value is the only variable that has been made in the field of transfers to the private sector.

Futurism, like a number of new and up-to-date methods in management, and especially sports management today, has a special place among modern research in this field, and because by carefully examining the fields of progress and issues facing organizations. In the near or distant future, individuals, sports, and even individuals will be examined and analysed. In addition to researchers, the target community will be doubly attractive. The concept of futurology refers to the systematic study, discovery, innovation, presentation, testing, and evaluation of a possible, probable, and desirable future. Futurism offers a variety of choices about the future for individuals and organizations and helps us choose and prioritize the most desirable future infrastructure. (Bill, 2011).

The most important goal of futurism is to identify new issues and how to deal with them, and to plan shortterm and long-term planning and prevent the harmful consequences of unforeseen events, and since sports can be different among different people according to the different goals of its users. Having a futuristic approach with different approaches; As a result, paying attention to the economic field in sports requires more codified and comprehensive planning, and considering that future research in the country's sports economy industry can provide the right path for senior managers in this field, and considering the unfavourable economic conditions in the country today. Targeted planning by identifying the desired future can lead to great profitability in the near future and will be the solution to many economic problems facing sports full of talent (Bakhsha et al., 2018).

Therefore, in line with the study innovation, the present study is based on the great importance of sports clubs and the impact they have on society, and very few studies have been conducted to evaluate this area in Iran. Considering the recent developments of Iran's FUTSAL in the world and also being publicly accepted in the society according to the honours obtained in recent years (winning several Asian club competitions, runner-up, third world competitions and won the title of the third best FUTSAL team in the world in 2019), and according to studies, there has been no research on the economic valuation of intangible assets of FUTSAL Premier League clubs. While the results of this study can be effective in advancing economic goals and attracting financial backers for federation and club officials, the answer to the question of what are the indicators of economic valuation of intangible assets of Iranian FUTSAL Premier League clubs?

\section{METHODOLOGY}

The present study is of $5 \%$ and 5 nature based on new methods of futuristic, analytical and exploratory science, which has been done by using a combination of qualitative and quantitative (mixed) data models. In order to identify the intangible assets of Iranian FUTSAL clubs, the research conducted in this field was studied. The statistical population of the present study was the official instructors of the federation and the coaches and managers of the clubs of the FUTSAL Premier League and the members of the scientific board who were experts in the field of FUTSAL. The number of samples continued to the level of information saturation (to the extent that the researcher did not obtain new information about intangible assets of Iranian FUTSAL clubs or the indicators proposed by the same and duplicate experts) (Danaeifard et al., 2013), as a whole Interviews with 29 selected members were semi-structured and conducted in person. In the open 
coding stage concepts were extracted. The text of the interviews was read several times and the words, phrases and preliminary list of factors were examined. In order to further validate the research, not only interviews but also documentary, library, scientific articles and previous research were used. Structural methods were used to classify the items. Finally, after receiving the opinion of experts and making corrections, the economic valuation questionnaire of intangible assets of Iranian FUTSAL clubs was set with 45 indicators in 5 factors. Then, a Delphi panel was formed using the questionnaire, the validity of which was confirmed by 65 experts and experts in sports and FUTSAL management, and three stages of Delphi were performed. Questionnaire in the form of five-value Likert scale questions (from one: very low value, two: low value, three: medium value, four: valuable, five: very valuable) to confirm the final items in three stages available to 45 formal instructors the federation and the coaches and managers of the clubs of the FUTSAL Premier League and the members of the scientific board of the experts were in the field of FUTSAL. After three steps of rejecting or approving the items by the experts by Delphi method, a relative consensus was obtained regarding the final variables of the research. As a result of this consensus, 44 main variables were approved, and 1 item was removed. Because dolphin is considered as a method or tool to support and develop studies and data should be supplemented with other tools and techniques. Therefore, in the present study, a combination of expert panel methods and cross-sectional matrix analysis has been used. Accordingly, 15 questionnaires were distributed exclusively between FUTSAL and academic elites who had sufficient expertise and experience in economic evaluation in FUTSAL. Score from 0 to 3 . The scoring of variables in the Mike Mac software is according to Table (1). The scores were then entered into a crosssectional matrix to measure the impact and impact (direct and indirect) of factors on the Mick Mac's future mapping software. Eventually, the variables are distributed across the coordinate axis. Based on the distribution of variables in the coordinate axis, their characteristics are determined and the basis of the analysis of the next steps is considered to obtain key indicators in the form of a graph as an output (Godet, 2006).

Table 1. Scores of variables in MicMac software.

\begin{tabular}{lccccc}
\hline Rank & $\mathbf{0}$ & $\mathbf{1}$ & $\mathbf{2}$ & $\mathbf{3}$ & $\mathbf{P}$ \\
\hline Concept & No effect & Weak effect & Medium effect & High effect & Potential effect \\
\hline
\end{tabular}

\section{FINDINGS}

Table 2. The results of the influential variables identified in Delphi periods.

\begin{tabular}{|c|c|c|c|c|c|c|}
\hline \multirow[b]{2}{*}{ Index } & \multirow[b]{2}{*}{ No } & Number of experts & \multirow{2}{*}{$\begin{array}{l}15 \\
\text { First } \\
\text { round } \\
\text { points }\end{array}$} & \multirow{2}{*}{$\begin{array}{l}15 \\
\text { Second } \\
\text { round } \\
\text { points }\end{array}$} & \multicolumn{2}{|l|}{15} \\
\hline & & Name the influential indicators & & & $\begin{array}{l}\text { Third } \\
\text { round } \\
\text { points }\end{array}$ & $\begin{array}{l}\text { Standard } \\
\text { Deviation }\end{array}$ \\
\hline \multirow{8}{*}{$\begin{array}{l}\text { Structural } \\
\text { capital }\end{array}$} & 1 & Veterans of the club & 3.53 & 3.80 & 3.53 & 0.75 \\
\hline & 2 & $\begin{array}{l}\text { Player, technical and } \\
\text { administrative staff education level }\end{array}$ & 3.40 & 3.53 & 4.26 & 0.97 \\
\hline & 3 & Club intellectual and social capital & 3.66 & 4.00 & 4.40 & 0.63 \\
\hline & 4 & Club certificates and licenses & 3.86 & 3.8 & 4.26 & 0.79 \\
\hline & 5 & The club's antiquity & 3.26 & 4.00 & 4.20 & 0.94 \\
\hline & 6 & Social status of club owners & 3.06 & 3.93 & 4.26 & 0.97 \\
\hline & 7 & $\begin{array}{l}\text { FUTSAL Development Document } \\
\text { (Vision, Mission, etc.) }\end{array}$ & 3.40 & 3.66 & 3.93 & 0.96 \\
\hline & 8 & $\begin{array}{l}\text { The organizational culture that } \\
\text { governs the club }\end{array}$ & 3.66 & 4.00 & 4.20 & 0.86 \\
\hline
\end{tabular}




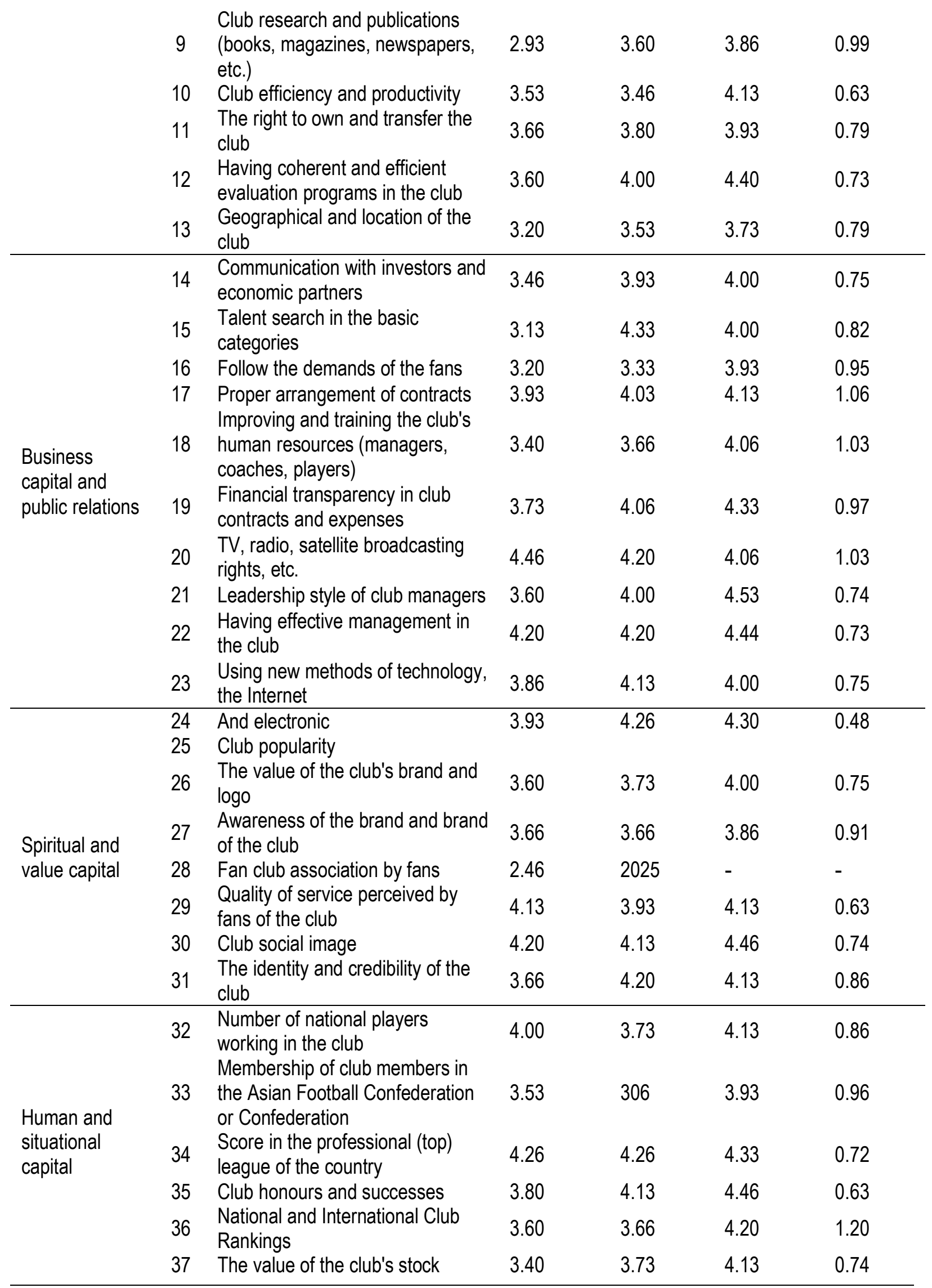




\begin{tabular}{|c|c|c|c|c|c|c|}
\hline & 38 & \multirow{2}{*}{$\begin{array}{l}\text { Club reputation in the community } \\
\text { The quota for participating in the } \\
\text { Asian and World Club Cup }\end{array}$} & 4.00 & 3.66 & 4.13 & 0.63 \\
\hline & 39 & & 4.00 & 4026 & 4.26 & 1.08 \\
\hline \multirow{6}{*}{$\begin{array}{l}\text { Communication } \\
\text { capital }\end{array}$} & 40 & \multirow{2}{*}{$\begin{array}{l}\text { Fan loyalty } \\
\text { Nickname of player, technical staff } \\
\text { and club managers }\end{array}$} & 4.13 & 4.26 & 4020 & 0.86 \\
\hline & 41 & & 4.33 & 4.26 & 4.73 & 0.45 \\
\hline & 42 & \multirow{4}{*}{$\begin{array}{l}\text { Achieve competitive advantage } \\
\text { Fan satisfaction with the positions } \\
\text { and position of the club } \\
\text { Number of fans } \\
\text { Experience coaching at the } \\
\text { national and international levels }\end{array}$} & 4.00 & 4.06 & 4.46 & 0.64 \\
\hline & 43 & & 3.73 & 3.80 & 4.46 & 0.63 \\
\hline & 44 & & 3.93 & 4.45 & 4.26 & 1.03 \\
\hline & 45 & & 4.20 & 4.44 & 4.53 & 0.63 \\
\hline
\end{tabular}

In order to identify the effective indicators in the economic valuation of intangible assets of clubs in the Iranian FUTSAL Premier League, 29 experts have been interviewed. For this purpose, the population-cognitive information of the respondents is as follows; Of the experts identified, 18 were men and 11 were women. Seven of them were official federation instructors, coaches and principals, five each, and 12 were university professors, two of whom had bachelor's degrees, 12 had master's degrees, and 15 had doctorates, aged 41 to 50 with 13 , have had the highest frequency in the age group. Among the several variables, 45 variables were extracted after several steps of reviewing and deleting similar cases. In three stages, in the form of a questionnaire, the subject experts were presented to evaluate and measure the criteria and value of each of these variables. At the end, 44 indicators were approved and one item with an average of less than 2.5 was eliminated (Delphi method). The following are the results of the influential variables identified in Delphi periods in Table (2).

The 44 Delphi extraction variables were evaluated by the statistical community in the form of a panel of the effects of the variables, the insertion and effect of each of the vertical column variables on the horizontal column and were evaluated with a range of 0 to 3 in the software. By analysing the key indicators and the required data, the dimensions of the $42 \times 42$ matrix with Mic Mac software and the method of analysing the cross-effects were $80.52 \%$ of the maturity of the matrix. Out of a total of 1559 measurable matrix relationships, 820 have intersecting 3 effects, meaning that indicators are both affected and influenced by each other. 442 Relationships have intersecting effects, i.e., they have played a reinforcing role. 297 Relationships have intersecting effects, i.e., they affect other indicators. 641 The relationship of cross-effects has neither affected nor affected each other. On the other hand, the matrix, based on the statistical index with 2 times the data rotation, has $100 \%$ utility and optimization, which indicates the high validity of the questionnaire and its answers. Table (3) shows the initial analysis of the matrix data.

Table 3. Preliminary analysis of matrix data.

\begin{tabular}{llllllll}
\hline $\begin{array}{l}\text { Dimensions } \\
\text { of the } \\
\text { matrix }\end{array}$ & Frequency & $\begin{array}{l}\text { Numbers of } \\
\text { zeros } \\
\text { (no effects) }\end{array}$ & $\begin{array}{l}\text { Numbers of } \\
\text { ones } \\
\text { (effectives) }\end{array}$ & $\begin{array}{l}\text { Numbers } \\
\text { of twos } \\
\text { (booster) }\end{array}$ & $\begin{array}{l}\text { Numbers of } \\
\text { threes } \\
\text { (Empowerment) }\end{array}$ & Total & $\begin{array}{l}\text { Fullness } \\
\text { degree }\end{array}$ \\
\hline 44 & 2 & 377 & 297 & 442 & 820 & 1559 & $80.52686 \%$ \\
\hline
\end{tabular}

In the matrix, the interaction effects of the sum of the numbers in the rows of each variable as the degree of influence and the columnar sum of each variable show its effectiveness from the other variables. The distribution of variables on the scattering page indicates the degree of stability or instability of the system. In total methodology and analysis, two types of distributions are defined, known as stable systems and unstable systems. In stable systems, the distribution of variables is English L; That is, some variables have a high 
impact. In a stable system, a total of three categories of variables can be observed: a: highly variable variables on the system (key factors), b: independent variables $\mathrm{c}$ : system output variables (result variables). In this system, the position of each of the factors is fully determined and its role can be clearly presented. In unstable systems, the situation is more complicated than a stable system. In an unstable system, Variables are scattered around the diagonal axis of the screen, and variables often indicate an intermediate state of influence and influence, which makes it very difficult to assess and identify key factors (Godet, 2006). From the scatter plot of variables affecting the valuation of intangible assets of FUTSAL Premier League clubs, according to Map (1), it is observed that the system is unstable, and while plotting the scattering of variables, variables that have high impact are revealed. The distribution status of the variables in the map (1) as well as the status of the influence and influence of the variables on each other are presented directly and indirectly in the following diagram: Which indicates the extent to which variables are affected and affected.

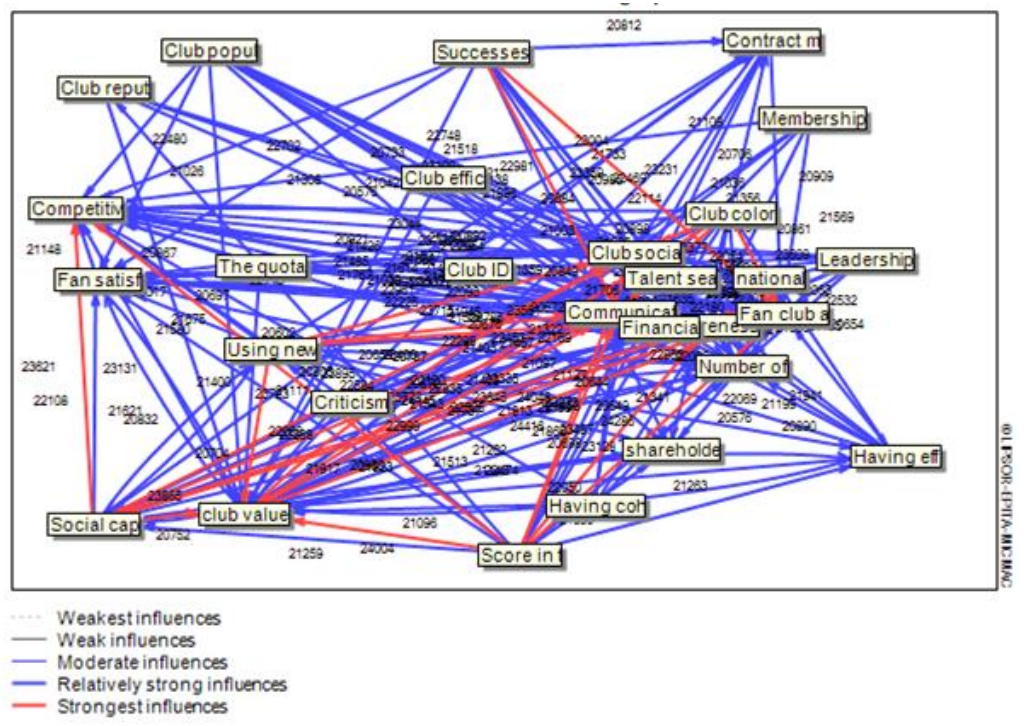

Figure 1. Potential indirect relationships between variables (very weak to very strong effects).

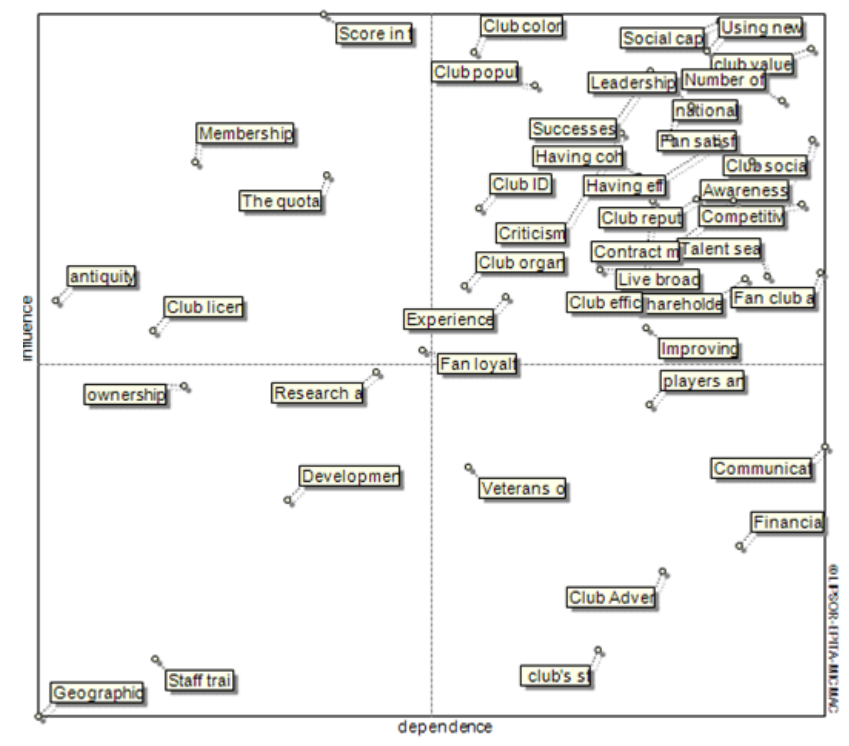

Figure 2. Indirect relationships between variables (very weak to very strong effects). 


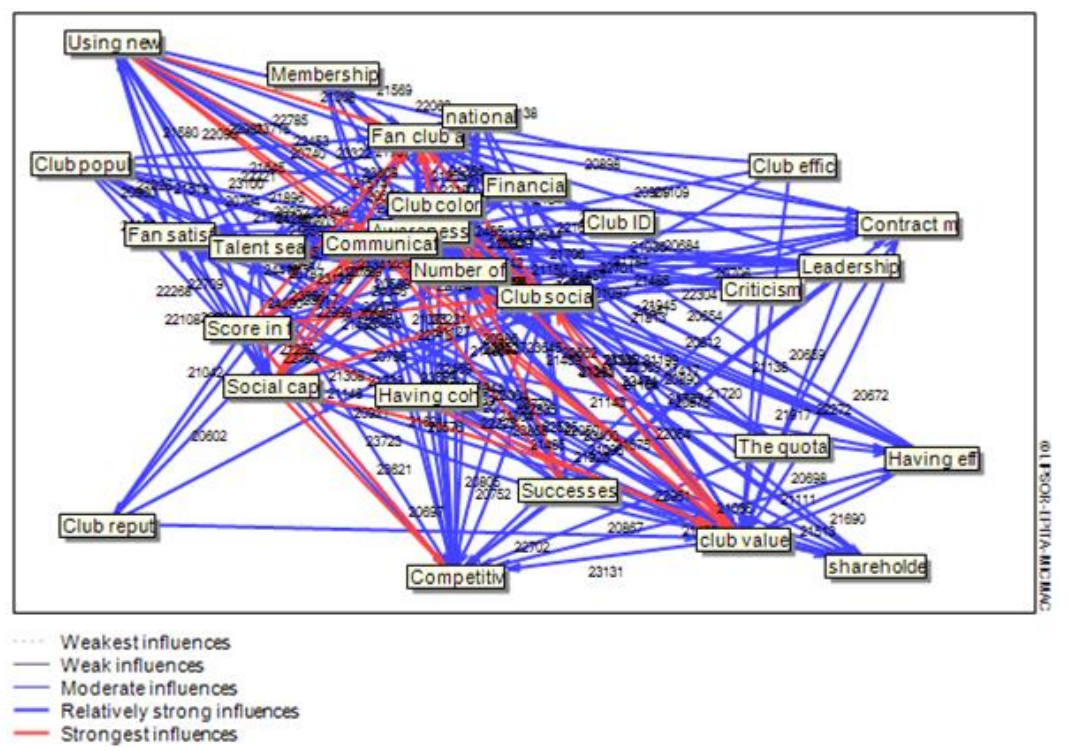

Figure 3. Potential direct relationships between variables (very weak to very strong effects).

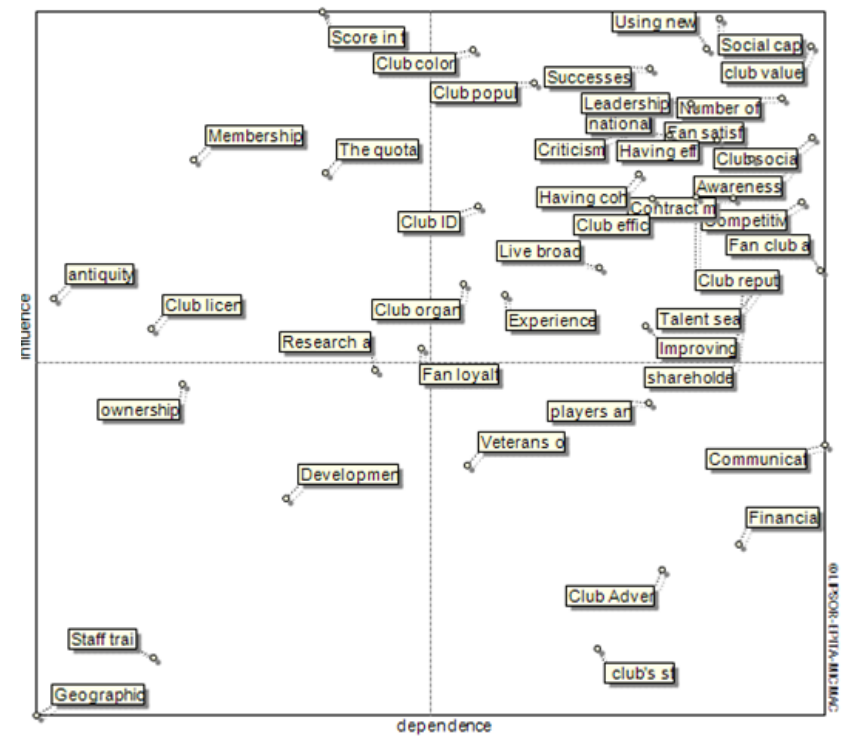

Figure 4. Distribution status of variables and display of key and strategic factors.

The results of analysing the cross-sectional effects based on the MDI and MII matrices show that 8 variables of club certificates, licenses and licenses, organizational culture governing the club, age, club identity and credibility, membership of club members in the federation and organization International FUTSAL scores, participation points in the country's premier league (professional league), quotas to participate in the Asian and World Club Cups, and loyalty of fans play an important role in improving system relations. These factors, which are located in the north-western part of the matrix, are the most important and influential indicators in the economic valuation of intangible assets of the country's FUTSAL premier clubs and the future of economic valuation of the country's FUTSAL clubs to develop this index. In addition, as can be seen from the distribution of variables, 25 of these factors are located in the first area (northeast), which have the highest impact and the least impact. These factors include; the value of the club's logo and brand, the club's national and 
international rankings, the club's popularity, the use of new technological, Internet and electronic methods, the leadership style of club managers, the number of national players working in the club, the pursuit of fan demands, intellectual and social capital, success and the honours gained by the club, the number of fans, the club's social image, awareness of the club's brand, having effective management in the club, correct arrangement of contracts, fans' satisfaction with the club's positions and position, gaining competitive advantage, club reputation, efficiency and interest Very Club, the social status of the club's owners, the association of the club's brand by the fans, the coaching experience of the technical staff at the national and international levels, the live television, radio, satellite broadcast of the games, the talent search in the basic FUTSAL categories by the clubs, the improvement and training human resources and having consistent and efficient evaluation programs in the club. Due to the economic conditions of the society, especially sports and FUTSAL, it is necessary to pay attention to these factors. Influential variables, or rather, variables of the result, include 6 variables, which are well-known variables (player and technical staff, managers), club veterans, communication with investors and economic partners, financial transparency in club contracts and costs, advertising and value. They are club stocks, low impact and very high impact; Therefore, they are very sensitive to the evolution of influential and two-sided variables. These variables are located in the southeastern part of the chart. Also, the variables of the club's development document, research and publications (books, magazines, newspapers, etc.), the club's ownership and transfer rights, the level of education of the players, the staff and administrative staff, and the geographical and spatial location of the club are independent variables. These variables are located in the southwestern part of the chart. Given the nature of system instability, some of these variables in this section of the page appear to have the nature of the system output, which should be called independent output variables. The results of analysing the effectiveness and effectiveness of each variable are given in Table (4).

Table 4. The effects of direct and indirect variables on each other.

\begin{tabular}{|c|c|c|c|c|c|c|c|c|c|}
\hline \multirow[b]{2}{*}{$\begin{array}{l}\frac{0}{0} \\
\frac{0}{\frac{0}{2}} \\
\frac{10}{5}\end{array}$} & \multirow[t]{2}{*}{ Index } & \multicolumn{2}{|c|}{ Direct effect } & \multirow[b]{2}{*}{ 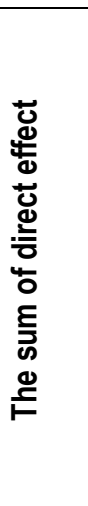 } & \multirow[b]{2}{*}{ 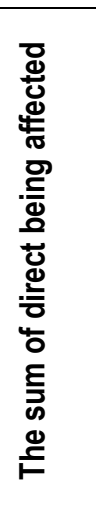 } & \multicolumn{2}{|c|}{ indirectly being affected } & \multirow[b]{2}{*}{ 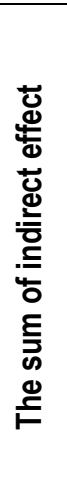 } & \multirow{2}{*}{ 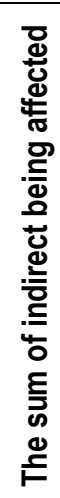 } \\
\hline & & 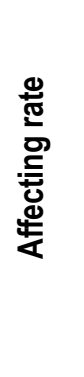 & 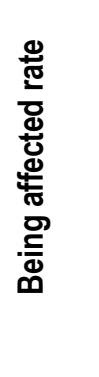 & & & 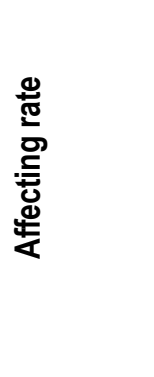 & 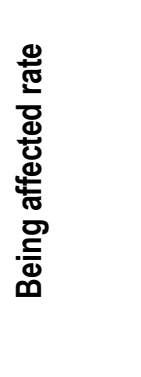 & & \\
\hline \multirow{8}{*}{ 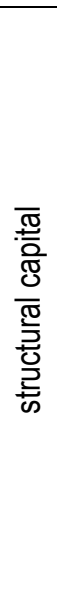 } & Veterans of the club & 96 & 67 & & & 494182 & 482963 & \multirow{8}{*}{ 尽 } & \multirow{8}{*}{ 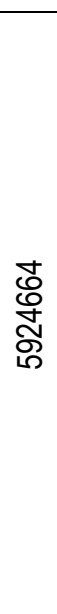 } \\
\hline & $\begin{array}{ll}\text { Player education level, } \\
\text { technical and administrative } \\
\text { staff }\end{array}$ & 21 & 51 & 727 & 981 & 162316 & 3773855 & & \\
\hline & $\begin{array}{l}\text { Club intellectual and social } \\
\text { capital }\end{array}$ & 108 & 102 & & & 760723 & 718299 & & \\
\hline & $\begin{array}{l}\text { Club certificates, licenses and } \\
\text { licenses }\end{array}$ & 25 & 79 & & & 159949 & 557890 & & \\
\hline & The club's antiquity & 6 & 81 & & & 56869 & 574723 & & \\
\hline & Social status of club owners & 109 & 83 & & & 787509 & 586523 & & \\
\hline & Development document & 48 & 65 & & & 302545 & 464816 & & \\
\hline & $\begin{array}{l}\text { The organizational culture that } \\
\text { governs the club }\end{array}$ & 68 & 81 & & & 490020 & 582524 & & \\
\hline
\end{tabular}




\begin{tabular}{|c|c|c|c|c|c|c|c|c|c|}
\hline & $\begin{array}{l}\text { Club research and publications } \\
\text { (magazines, } \\
\text { newspapers, etc.) }\end{array}$ & 53 & 74 & & & 396535 & 535223 & & \\
\hline & Club efficiency and productivity & 93 & 87 & & & 689655 & 629316 & & \\
\hline & $\begin{array}{l}\text { The right to own and transfer } \\
\text { the club }\end{array}$ & 27 & 74 & & & 192949 & 527607 & & \\
\hline & $\begin{array}{l}\text { Having coherent and efficient } \\
\text { evaluation programs in the club }\end{array}$ & 94 & 89 & & & 675332 & 642775 & & \\
\hline & $\begin{array}{l}\text { Geographical and location of } \\
\text { the club }\end{array}$ & 6 & 48 & & & 38686 & 345733 & & \\
\hline \multirow{10}{*}{ 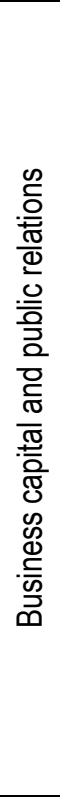 } & $\begin{array}{l}\text { Communication with investors } \\
\text { and economic partners }\end{array}$ & 123 & 69 & \multirow{10}{*}{1047} & \multirow{10}{*}{834} & 872339 & 494239 & \multirow{10}{*}{ 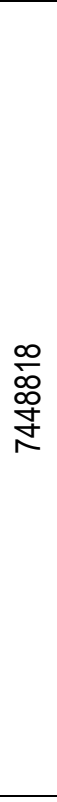 } & \multirow{10}{*}{ 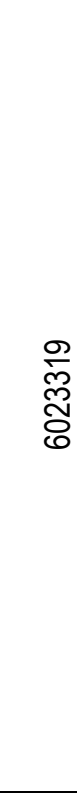 } \\
\hline & $\begin{array}{l}\text { Talent search in the basic } \\
\text { categories }\end{array}$ & 115 & 82 & & & 811011 & 587765 & & \\
\hline & Follow the demands of the fans & 80 & 92 & & & 656427 & 666593 & & \\
\hline & $\begin{array}{lll}\begin{array}{l}\text { Proper } \\
\text { contracts }\end{array} & \text { arrangement } & \text { of } \\
\end{array}$ & 109 & 87 & & & 775169 & 6295154 & & \\
\hline & $\begin{array}{l}\text { Improving and training human } \\
\text { resources }\end{array}$ & 96 & 77 & & & 682616 & 559480 & & \\
\hline & $\begin{array}{l}\text { Financial transparency in club } \\
\text { contracts and expenses }\end{array}$ & 110 & 59 & & & 781291 & 439605 & & \\
\hline & $\begin{array}{l}\text { The right to broadcast } \\
\text { television, radio, satellite, etc. }\end{array}$ & 88 & 80 & & & 633702 & 591480 & & \\
\hline & $\begin{array}{l}\begin{array}{l}\text { Leadership style of } \\
\text { managers }\end{array} \\
\end{array}$ & 103 & 96 & & & 730461 & 681485 & & \\
\hline & $\begin{array}{l}\text { Having effective management } \\
\text { in the club }\end{array}$ & 107 & 92 & & & 758225 & 661574 & & \\
\hline & $\begin{array}{l}\text { Use of technology, Internet and } \\
\text { electronic methods }\end{array}$ & 106 & 100 & & & 747575 & 711638 & & \\
\hline \multirow{7}{*}{ 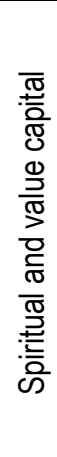 } & Club popularity & 71 & 98 & \multirow{7}{*}{790} & \multirow{7}{*}{613} & 564738 & 692872 & \multirow{7}{*}{ 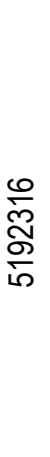 } & \multirow{7}{*}{ 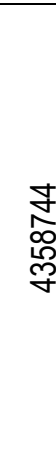 } \\
\hline & $\begin{array}{l}\text { The value of the club's brand } \\
\text { and logo }\end{array}$ & 133 & 101 & & & & & & \\
\hline & $\begin{array}{l}\text { Awareness of the brand and } \\
\text { club brand }\end{array}$ & 121 & 92 & & & 839133 & 649114 & & \\
\hline & Fan club association by fans & 124 & 83 & & & 867448 & 589984 & & \\
\hline & Club social image & 123 & 92 & & & 858789 & 662877 & & \\
\hline & $\begin{array}{l}\text { The identity and credibility of } \\
\text { the club }\end{array}$ & 65 & 88 & & & 505479 & 6252112 & & \\
\hline & Club ads & 98 & 59 & & & 700114 & 425634 & & \\
\hline \multirow{7}{*}{ 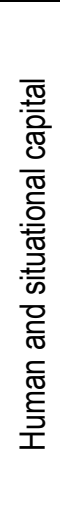 } & $\begin{array}{l}\text { Number of national players } \\
\text { working in the club }\end{array}$ & 102 & 91 & & & 707877 & 664027 & \multirow{7}{*}{ 离 } & \multirow{7}{*}{ 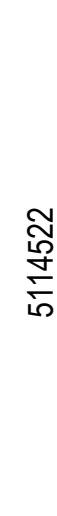 } \\
\hline & $\begin{array}{l}\text { Membership of club members in } \\
\text { federations and international } \\
\text { organizations }\end{array}$ & 30 & 91 & 579 & 712 & 204779 & 650642 & & \\
\hline & $\begin{array}{l}\text { Score in the country's premier } \\
\text { league }\end{array}$ & 41 & 103 & & & 340890 & 731891 & & \\
\hline & Club honours and successes & 95 & 98 & & & $91 \times 119$ & 700733 & & \\
\hline & $\begin{array}{l}\text { National and International Club } \\
\text { Rankings }\end{array}$ & 70 & 99 & & & 500092 & 711026 & & \\
\hline & The value of the club's stock & 87 & 53 & & & 631742 & 382375 & & \\
\hline & Club reputation & 105 & 87 & & & 735978 & 630346 & & \\
\hline
\end{tabular}




\begin{tabular}{|c|c|c|c|c|c|c|c|c|c|}
\hline & $\begin{array}{l}\text { The quota for participating in } \\
\text { the Asian and World Club Cup }\end{array}$ & 49 & 90 & & & 344243 & 643482 & & \\
\hline \multirow{6}{*}{ 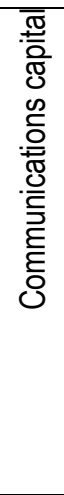 } & Fan loyalty & 59 & 77 & \multirow{6}{*}{573} & \multirow{6}{*}{501} & 445425 & 547251 & \multirow{6}{*}{ 离 } & \multirow{6}{*}{$\begin{array}{c}\bar{T} \\
\dot{\delta} \\
\dot{d}\end{array}$} \\
\hline & $\begin{array}{l}\text { Nickname (player, technical } \\
\text { staff and club managers) }\end{array}$ & 97 & 71 & & & 686063 & 517271 & & \\
\hline & Achieve competitive advantage & 119 & 88 & & & 847866 & 627521 & & \\
\hline & $\begin{array}{l}\text { Fan satisfaction with the } \\
\text { positions and position of the } \\
\text { club }\end{array}$ & 113 & 90 & & & 794915 & 651137 & & \\
\hline & Number of fans & 117 & 95 & & & 826715 & 684419 & & \\
\hline & $\begin{array}{l}\text { Experience coaching technical } \\
\text { staff at national and } \\
\text { international levels }\end{array}$ & 73 & 80 & & & 534883 & 576572 & & \\
\hline
\end{tabular}

One of the comparisons of the results of the analysis of direct and indirect effects is the finding of key factors affecting the economic valuation of intangible assets of clubs in the Iranian FUTSAL Premier League. And they have a high impact. To validate the Mic-Mac software analytics section (because this method is a kind of decision-making method), the panel of experts in the field of economic valuation was used. The first 25 key factors in the economic valuation of intangible assets of FUTSAL Premier League clubs were discussed, and the results of this validation are given in Table (5).

Table 5. Key factors extracted in the economic valuation of intangible assets.

\begin{tabular}{l} 
Key primary factors extracted \\
\hline 1. Fan satisfaction with the positions and position of the club, 2. Achieving competitive advantage, 3. Club \\
reputation, 4. Number of national players working in the club, 5. Club Social Image, 6 . Fan brand \\
association by fans, 7. Brand awareness, 8. Using new methods of Internet and electronic technology, 9 . \\
Having effective management in the club, 10. Leadership style of club managers, 11. The value of the \\
club's logo and brand, 12. Talent Search for Basic FUTSAL Categories by Clubs Number of national \\
players working at the club, 14. National and International Club Rankings, 15. The club's intellectual and \\
social capital, 16. Having coherent and efficient club evaluation programs, 17. Improving and training \\
human resources, 18. Club Popularity, 19. Number of national players working at the club, 20. Following \\
the demands of the fans, 21. Efficiency and productivity in the club, 22. Proper arrangement of contracts, \\
23. Social status of club owners, 24. Club honours and success. 25. Number of fans.
\end{tabular}

\section{CONCLUSIONS AND SUGGESTIONS}

Sports clubs are one of the main components of the sports industry. FUTSAL is one of the sports clubs that has been mentioned as the core of the sports industry, which is like an economic enterprise (Janin, 2017). FUTSAL is a complex and dynamic game due to the adjustment of factors that directly affect the mental and physical activity and the emergence of the game (Martiz et al., 2018) and an evolving sport that It has attracted a lot of fans around the world (Moore et al., 2014). In today's economy, intangible assets are vital to the survival and maintenance of competition and the performance of clubs. The attention and recognition of the intrinsic values of clubs and the amount of intangible assets of a club can be considered as a factor for club growth and development. Studies and research backgrounds show that not only is there no specific method for valuing assets in the Iranian sports industry, but also that capitalists are unaware of its value and ignore it (Hosseini, 2014). While valuing, identifying and identifying intangible assets and its components in FUTSAL and the Premier League can be used to inform investors, managers of sports clubs, club officials, stakeholders and Relevant stakeholders are effective and important in advancing their economic goals and 
gaining their competitive advantage. Since few studies have been conducted on the valuation of intangible assets of sports clubs in Iran, the importance of further studies to identify non-market values, especially from various dimensions affecting social components as well as influencing fans Sports clubs' double. The emergence of a club's economic value among rivals and sponsors depends on the economic attitude of clubs as a sports brand, which indirectly affects the club's financial strength. To this end, the present study, by combining the methods of the panel of experts and the analysis of the cross-sectional matrix (MicMac), identified the indicators of economic valuation of intangible assets of clubs in the Iranian FUTSAL Premier League.

The formation of the Delphi panel and the findings of the Delphi periods ( 3 rounds) were indicative of the mean scores above average. Finally, the present study confirmed 44 items in the form of 5 indicators; Structural capital, commercial and public relations capital, spiritual and value capital, human and situational capital, and communication capital, identified and summarized the valuation indicators of intangible assets of FUTSAL Premier League clubs in Iran. The findings of the present study are similar to those of Brookings (1996), Bontis (2002), Chen et al. (2004), Capila et al. (2012), and Salonius and Lancouvis (2012), who divided an organization's assets into four sections: human capital. Spiritual capital, structural capital, and communication capital have been matched, as well as research by Bakhsha et al. (2018), which divided an organization's assets into three categories: communication capital, structural capital, and human capital. It should be noted that all research conducted is different from the present study in that it does not examine intangible assets together in organizations and clubs.

Based on the results of MicMac software output, the variables influencing the economic valuation of intangible assets are identified and after prioritizing these variables, from the perspective of panel views, the introduction of the 55 key factors is introduced. Symmetry of the map (1) and obtaining the opinion of experts in relation to economic valuation, the role of indicators of business capital and spiritual public relations with 8 key factors influencing; Talent identification in FUTSAL by clubs, handling and tracking of fans' demands, proper arrangement of contracts, improvement and training of human resources, TV, radio and satellite broadcasting rights, leadership style of club managers, having effective management in the club and using new technological methods The Internet and e-commerce are more prominent than the other four dimensions as key variables, which is probably due to the fact that for panellists, given their experience in FUTSAL, these dimensions and sub-indicators are factors that are less common within FUTSAL clubs. It has been noted that perhaps comparing FUTSAL league clubs with other ball sports, such as football league clubs and volleyball league clubs, and seeing the points of difference, has been influential in this type of comment and identification.

Structural capital factor with 4 indicators, spiritual and value capital with 5 indicators, human and situational capital with 4 indicators and communication capital with 4 key effective indicators, important factors from the perspective of experts and experts in valuing assets The FUTSAL players of the FUTSAL Premier League club are unhappy. Accordingly, the results of this part of the study can be compared with the results of a study by Pinargorel et al. (2013) who later mentioned human capital in their classification as an influential factor in the division of intangible assets. Since in economic valuation, only obvious assets are usually considered, the establishment of an economic valuation system of intangible assets in FUTSAL clubs requires a proper cultural context and the realization of a set of measures. Therefore, considering the identification of effective indicators in the economic valuation of intangible assets of clubs, it is recommended to managers, investors and officials of the FUTSAL Committee of the Federation that according to the importance and role of each of these indicators. In order to improve the quality and quantity of FUTSAL clubs and finally our national FUTSAL team, it is better to pay attention to these indicators as factors that are 
effective in promoting the success and branding of FUTSAL clubs, which will attract more financial sponsors. The club and the survival and financial and non-financial stability of that club. In order to inform many managers with intangible assets and its importance, necessary practical and operational training courses should be held. Highlighting and highlighting intangible assets such as brand value, number and satisfaction of fans, having effective management, leadership style of club managers, financial transparency, investors, fans and financial sponsors are familiar with these capabilities and they are in Attention to FUTSAL Premier League clubs attracted and encouraged.

\section{REFERENCES}

Abdi, Sh., Zangiabadi, M., \& Talibpour, M. (2016). Determining the Role of Factors Affecting the Evaluation of Iranian Football Premier League Players. Journal of Human Resource Management in Sports, (3) 2: 136-121.

Adli, F., \& Mohammadi, J. (2013). Comparison of intangible assets of higher education system with industrial system based on source-based theory. Quarterly Journal of Iranian Higher Education Association, 5(3): 85-115.

Asmild, M., Paradi, J.C., \& Pastor, J.T. (2009). Centralized resource allocation BCC models. Omega, 37, 40-49. https://doi.org/10.1016/j.omega.2006.07.006

Bakhsha, A., Afrazeh, A., \& Esfahanipour, A. (2018). Identifying the Variables of Intellectual Capital and Its Dimensions with the Approach of Structural Equations in the Educational Technology of Iran. EURASIA Journal of Mathematics, Science and Technology Education, 14(5), 1663-1682. https://doi.org/10.29333/ejmste/85037

Bauman, M.P., \& Shaw, K.W. (2018). Value relevance of customer-related intangible assets. Research in Accounting Regulation, 30(2), 95-102. https://doi.org/10.1016/j.racreg.2018.09.010

Bianchi, P. (2017). The economic importance of intangible assets. Routledge. https://doi.org/10.4324/9781351147002

Biscaia, R., Correia, A., Ross, S., Rosado, A. F., \& Maroco, J. (2013). Spectator-based brand equity in professional soccer. Sport Marketing Quarterly, 22, 20-32.

Bontis, N., \& Fitz-Enz, J. (2002). Intellectual capital ROI: a causal map of human capital antecedents and

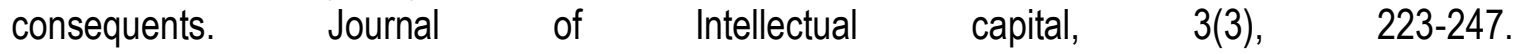
https://doi.org/10.1108/14691930210435589

Brooking, A. (1996). IC. Core Asset for the Third Millennium Enterprise. Journal of Intellectual Capital, 1 10.

Chen, J., Zhu, Z., \& Yuan Xie, H. (2004). Measuring intellectual capital: a new model and empirical study. Journal of Intellectual capital, 5(1), 195-212. https://doi.org/10.1108/14691930410513003

Christos, F. (2014), Football and Stock Returns: New Evidence. International Conference on Applied Economics (ICOAE) 2014. Procedia Economics and Finance, 14, 201 - 209. https://doi.org/10.1016/S2212-5671(14)00703-5

da Silva, W.R., Freitas, K., Carvalho, H.D., Ferrari, E., Vieira, M., \& Cardoso, F.L. (2018). Satisfaction with life and subjective social status in athletes of indoor soccer and soccer. Revista Brasileira de Ciências do Esporte, 40(4), 374-380. https://doi.org/10.1016/j.rbce.2018.02.001

Danaeifard, H., Azar, A., \& Ebrahimi, S.A. (2013). Reviewing strategies to improve the political, social, administrative and technical viability of the country's public policies using evidence-based policymaking approach. Quarterly Journal of Public Organization Management, 1(3), 17-34.

Elahi, A. (2005). Investigating the performance of the Professional Football League of the Islamic Republic of Iran and comparing it with the Japan Professional Football League. Master Thesis, Faculty of Physical Education and Sports Sciences, University of Tehran. 
Fathollahzadeh, A. (2009). Football Privatization: Concepts and Strategies, Life Days Publications.

Ferdman, R.A., \& Yanofsky, D. (2013). Latin America earns more from exporting soccer players than live animals. Area of circle is proportion to amount of trade Data: Euro metrics Sport Marketing, International Trade Center.

Godet, M. (2006). Creating Futures: Scenario Planning as a strategic management tool (pp. 280). Washington, DC: Economica. Economica Brookings diffusion.

Hosseini, M. (2014). Designing a conceptual model for displaying intangible assets of clubs in the Iranian Professional Football League. PhD thesis, Faculty of Physical Education, University of Tehran.

Houlihan, L. (2015). Purchase price allocation study. Los Angeles Press.

Izadiar, M., Memari, J., Mousavi, M.H. (2016). Equation of the pricing of the players of the Iranian Football Premier League. Economic Research, (1)51, 40-25.

Janin, F. (2017). When being a partner means more: The external role of football club management accountants. Management Accounting Research, 35, 5-19. https://doi.org/10.1016/j.mar.2016.05.002

Kapyla, J., Kujansivu, P., \& Lönnqvist, A. (2012). National intellectual capital performance: a strategic $\begin{array}{llll}\text { approach. Journal of Intellectual } & \text { Capital, 13(3), 343-362. }\end{array}$ https://doi.org/10.1108/14691931211248909

Maleki Choobari, M. (2010). Football Club Accounting. Accounting Quarterly. No. 17.

Manel L, Jean Franc,ois G, (2019). Does increased disclosure of intangible assets enhance liquidity around new equity offerings? Research in International Business and Finance, 48, 426-437. https://doi.org/10.1016/j.ribaf.2019.01.009

Martins, C., et al. (2018). Motivation for female FUTSAL practice. The European Proceedings of Social \& Behavioural Sciences, 42, 80-91. https://doi.org/10.15405/epsbs.2018.06.02.9

Masala, A., Bonacin, D., Bonacin, D., (2009). Sports success prediction models in team sports of football, basketball, handball and volleyball. Acta Kinesiologica, 2, 49-54.

Moghadam, M. H. V., Mohammadi, M., \& Bazaey, G. A. (2020). Investigating effect of transformational leadership on employees' and administrators' satisfaction of telecommunication general department of district 3. Journal of management and accounting studies, 8(2).

Moore, R., (2014). A systematic review of FUTSAL literature. American Journal of Sports Science and Medicine, 2(3), 108-116. https://doi.org/10.12691/ajssm-2-3-8

Neubig, T., \& Wunsch-Vincent, S. (2018). Tax distortions in cross-border flows of intangible assets. International Journal of Innovation Studies, 2(3), 101-121. https://doi.org/10.1016/j.ijis.2018.08.003

Pamela Wicker (2011), Willingness-to-Pay in Non-Profit Sports Clubs. International Journal of Sport Finance, 6, 155-169.

Pinar Gurel, S., Dagli Ekmekci, Y.A., \& Küçükkaplan, İ. (2013). Measuring intellectual capital for football clubs: evidence from Turkish first division football league. Pamukkale Journal of Sport Sciences, 4(1), 36-47.

Plambeck, E.L., \& Taylor, T.A. (2013). On the value of input efficiency, capacity efficiency, and the flexibility tore balance them. Manufacturing \& Service Operations Management,15(4),630-639. https://doi.org/10.1287/msom.2013.0444

Preuss, H., \& Werkman, K. (2011), Erlebniswert Olympischer Winterspiele in München 2018, Sport und Gesselschaft, 8, 97-123.

Rahmani, A., \& Ismaili Kia, Gh. (2014). Intangible assets in listed companies and their impact on the value relationship of profits. Quarterly Journal of Experimental Financial Accounting Studies, 1, 4311. 
Rostamzadeh, P., Sadeghi, H., Assari, A.S., \& Yavari, K. (2014). The effect of investment in sports on economic growth in Iran. Quarterly Journal of Economic Research (Sustainable Growth and Development), 14(4), 210-177.

Sahebkaran, M.A. (2018). Designing the economic evaluation model of Iranian volleyball clubs. PhD dissertation in the field of physical education, strategic management orientation in sports organizations, Faculty of Physical Education and Sports Sciences, Ferdowsi University of Mashhad.

Salonius, H., \& Lönnqvist, A. (2012). Exploring the policy relevance of national intellectual capital information. Journal of Intellectual Capital, 13(3), 331-342. https://doi.org/10.1108/14691931211248891

Sarlab, R., \& Sarlab, M. (2014). The effect of exchange rate on the export trend of Iranian sports goods (2001-2010). First National Conference on Applied Economics and Management with a National Approach.

Shin, N., Kraemer, K.L., \& Dedrick, J. (2017). R\&D and firm performance in the semi conduct or industry. Industry and Innovation, 24(3), 280-297. https://doi.org/10.1080/13662716.2016.1224708

Travassos, B., Coutinho, D., Gonçalves, B., Pedroso, P., \& Sampaio, J. (2018). Effects of manipulating the number of targets in U9, U11, U15 and U17 FUTSAL players' tactical behaviour. Human movement science, 61, 19-26. https://doi.org/10.1016/..humov.2018.06.017

Zamani, M. et al. (2012). The effect of sports expenses on Iran's gross domestic product. Journal of Sports Management, 4(15), 143-156.

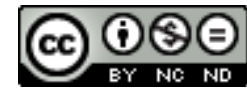

This work is licensed under a Attribution-NonCommercial-NoDerivatives 4.0 International (CC BY-NC-ND 4.0). 